\title{
Desmoplastic Small Round Cell Tumor of the Ovary: A Case Report with a New Modality of Treatment and Review of the Literature
}

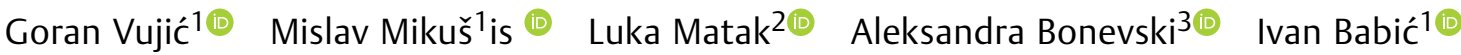 \\ Pavao Planinić ${ }^{10}$ Damir Babić1 ${ }^{\circledR}$ Ante Ćorušić ${ }^{10}$
}

${ }^{1}$ Department of Obstetrics and Gynecology, University Hospital Center Zagreb, Zagreb, Croatia

2 Department of Obstetrics and Gynecology, General Hospital Zadar,

Address for correspondence Mislav Mikuš, Department of Obstetrics and Gynecology, University Hospital Center Zagreb, Zagreb, Croatia Zadar, Croatia

${ }^{3}$ Department of Oncology and Hematology, Children's Hospital

Zagreb, Zagreb, Croatia

Rev Bras Ginecol Obstet 2020;42(5):297-302

\author{
Abstract \\ Keywords \\ - desmoplastic small \\ round cell tumor \\ - ovary \\ - surgical debulking \\ - adjuvant \\ chemotherapy \\ - radiotherapy \\ - immuno- \\ histochemistry
}

Objective Desmoplastic small round cell tumor (DSRCT) is a rare intraabdominal neoplasm that grows along serosal surfaces and is primarily found in young men. To date, only 16 cases of ovarian DSRCT have been previously reported in women in the English literature, and no large population-based studies on this topic exist.

Case Report We report the case of a 19-year-old virgo with unremarkable past medical history, initially presented with abdominal fullness. After being treated with the optimal treatment modality (primary and secondary surgical debulking, unique chemotherapy, protocol and adjuvant radiotherapy), the patient has remained without tumor disease for 40 months.

Conclusion Although the best therapy for patients with DSRCT has yet to be determined, combining complete surgical resection, adjuvant chemotherapy, and radiotherapy is required to prolong survival and to achieve proper quality of life.

\section{Introduction}

Desmoplastic small round cell tumor (DSRCT) is a highly malignant, rare intraabdominal neoplasm of mesenchymal origin with an extremely poor prognosis. It primarily affects young men, with a reported male to female ratio of four to one. ${ }^{1}$ Desmoplastic small round cell tumor has a propensity for serosal surfaces, and the majority of the patients are in the late stages of the disease upon presentation. ${ }^{2}$ Owing to the male predominance of this disease, DSRCT is rarely noticed in young women with an abdominal or ovarian mass, so it presents a considerable diagnostic challenge. Furthermore, given the overall low incidence rate, ${ }^{3}$ uncertain histogenesis, and the diffuse nature of DSRCT, there is no consensus on the most effective treatment modality. Up to

received

July 15, 2019

accepted

March 2, 2020 DOI https://doi.org/
10.1055/s-0040-1710350.
ISSN $0100-7203$. now, only 16 cases of ovarian DSRCT have been previously reported in women in the English literature, and no large population-based studies on this topid exist. ${ }^{2}$ The present report describes a case of DSRCT in a young woman who initially presented with right ovarian mass and consequent abdominal distension. The aim of the current review is to highlight all the issues encountered in diagnosing and treating the DSRCT.

\section{Case Presentation}

A 19-year-old nulliparous virgo, with unremarkable past medical history, initially presented to our department with a feeling of abdominal fullness. Pelvic examination revealed a

Copyright $\odot 2020$ by Thieme Revinter Publicações Ltda, Rio de Janeiro, Brazil
License terms

(c) (1) 
painless right adnexal mass that was occupying the whole abdominal cavity. The mass was firm, solid, of low mobility, and with hard-to-define boundaries. Transabdominal and transvaginal ultrasonography revealed a predominantly solid and vascularized, bilateral adnexal formation with an area of $80 \mathrm{~mm}$. The level of the serum carbohydrate antigen-125 was elevated to $271 \mathrm{U} / \mathrm{ml}$ (normal, $<35 \mathrm{U} / \mathrm{ml}$ ), while other serum tumor markers ( $\beta$-HCG, AFP) were not elevated. The patient underwent an exploratory laparotomy. Approximately $1,000 \mathrm{ml}$ of amber-colored cytologically negative ascites were withdrawn intraoperatively. Two large, irregular, and predominantly solid, bilateral ovarian masses (both $\sim 20 \mathrm{~cm}$ ) were found with small tumor implants on the sigmoid colon, omentum, and cul-de-sac. The interiliac lymph nodes measured $4 \mathrm{~cm}$, bilaterally. Using intraoperative frozen section diagnosis, the tumor tissue of right ovary was interpreted as a malignant tumor, probably dysgerminoma. A bilateral salpingo-oophorectomy, bilateral pelvic lymphadenectomy, total abdominal hysterectomy, complete omentectomy, and resection of the disseminated tumors with interiliac lymph node excision were performed. The patient was optimally debulked with no residual tumor seen. Macroscopically, the right and the left ovarian masses were pearly white, predominantly solid with partially pseudocystic areas and necrosis. Conventional hematoxylin and eosin stained sections demonstrated small and round tumor cell nests separated by a prominent desmoplastic stroma. The mitotic count of the tumor cells was high (up to 26 mitotic figures per 10 high power fields), suggesting a poorly-differentiated carcinoma. Immunohistochemical staining was performed using the antigen retrieval technique. The tumor cells were diffuse positive for broadspectrum cytokeratins (CK AE1/AE3), epithelial membrane antigen (EMA), and vimentin. Polymerase chain reaction (PCR) analysis showed positive results for Ewing sarcoma (EWS)-Wilms tumor 1 (WT1) fusion gene, while additional confirmation of the DSRCT diagnosis was made via detection of the tumor-specific chromosomal translocation $t(11 ; 22)$ (p13;q12). Based on the morphology and immunohistochemistry findings, a final diagnosis of intraabdominal DSRCT with ovarian involvement was made. Bone marrow biopsy was performed after a final pathologic diagnosis and within three weeks after surgery, revealing normocellular pattern. Furthermore, a PET/CT scan demonstrated enlarged paraaortic lymph node in projection of third lumbar vertebrae with cluster of hyperdense nodes beside it, without metabolic activity. According to the CWS 2009 protocol scheme, she has received intensive chemotherapy treatment for metastatic disease: 3 cycles of ifosfamide $9,000 \mathrm{mg} / \mathrm{m}^{2}$, vincristine $1,5 \mathrm{mg} / \mathrm{m}^{2}$, actinomycin $1,5 \mathrm{mg} / \mathrm{m}^{2}$ (IVA), 3 cycles of carboplatin $500 \mathrm{mg} / \mathrm{m}^{2}$, epirubicin $150 \mathrm{mg} / \mathrm{m}^{2}$, Vincristine $1.5 \mathrm{mg} / \mathrm{m}^{2}(\mathrm{CEV})$, and 3 cycles of ifosfamide $9,000 \mathrm{mg} / \mathrm{m}^{2}$, vincristine $1,5 \mathrm{mg} / \mathrm{m}^{2}$, etopozide $450 \mathrm{mg} / \mathrm{m}^{2}$ (IVE) with informed consent of the patient and her family. Only in first cycle of IVA and in the first cycle of CEV she has received vincristine $3 \times 1.5 \mathrm{mg} / \mathrm{m}^{2}$. Because of suspect malignancy propagation on positron emission tomography/computed tomography (PET/CT) scan, we conducted a second debulk- ing surgery (SDS), about 4 months after initial surgical treatment. Intraoperative finding was a solid tumor $(9 \times 5 \mathrm{~cm})$, barely fixed with external iliac vessels. We performed successful tumor resection with no residual tumor seen in the abdominal cavity. Cytological and immunohistochemistry findings confirmed diagnosis of DSRCT. The patient received nine cycles of CWS protocol overall. After the ninth cycle of CWS protocol, a disease remission was accomplished, and the patient underwent high-dose chemotherapy (busulfan $600 \mathrm{mg} / \mathrm{m}^{2}$, melphalan $140 \mathrm{mg} / \mathrm{m}^{2}$ ) followed by autologous stem cell support. After the autologous stem cell support, she received a couple of cycles of maintenance therapy (etoposide $2 \times 25 \mathrm{mg} / \mathrm{m}^{2} /$ day, idarubicin $4 \times 5 \mathrm{mg} / \mathrm{m}^{2}$ and trofosfamide $2 \times 75 \mathrm{mg} / \mathrm{m}^{2} /$ day) but, due to drug induced high transaminase levels, we stopped it. The transaminase levels have normalised soon after. Twelve months after the patient's admission, a control PET/CT scan, pelvic and abdominal MRI were without evidence of eventual disease reccurence. In accordance with the above mentioned clinical findings, our approach was to provide a radiotherapy to the site of initial bulk disease (dose of $30.6 \mathrm{~Gy}$ divided in 17 fractions). The only noticeable adverse effect during the course of therapy was thrombocytopenia, which was extensive at one point, so it required treatment with intravenous immunoglobulins and platelet transfusion. Up to date, she is in good general condition without evidence of disease reccurence, 40 months after her initial diagnosis.

\section{Discussion}

Desmoplastic small round cell tumor was first described in 1989 by Gerald and Rosai ${ }^{4}$ as a rare tumor of uncertain histogenesis. The presenting symptoms of DSRCT are usually related to the site of involvement, such as crampy abdominal pain, abdominal distension with ascites, palpable mass, constipation, anorexia, or weight loss. ${ }^{1,2}$ The most common primary location of DSRCT is the peritoneal cavity, but it can be found at other sites, such as the ovary, kidney, or retroperitoneal space. ${ }^{5}$ Primary DSRCT has also been reported in the posterior cranial fossa, scalp, ethmoidal sinuses, paratesticular region, pleura, and chest. 6,7 The typical sites of metastas isinclude the groin, neck or mediastinum, lymph nodes, liver, lungs, and bone marrow $(5,10)$. Although the tumor markers in our case were within th reference values range, $\beta$-HCG, AFP, $\mathrm{LDH}$, and CA- 125 should be measured in all young women who present with a pelvic mass. Elevated serum tumor marker levels may serve as an adjunct in the initial diagnosis, therapy monitoring, and posttreatment surveillance. Conforming to tumor rarity and certain aggressive nature, it has low overall survival rates with reported 3-year survival of $29 \%{ }^{8}$ and median progression-free survival of 2.6 years. ${ }^{9,10}$ The overall progression-free 5 -year survival rate of patients is $18 \%{ }^{11}$ The mean age of affected women reported up to this point is 20 years with life expectancy range from 4 to 42 months ( - Table 1). Due to the rare occurrence of this disease, with up to 0.5 cases/million, ${ }^{3}$ a definitive diagnosis is only obtained based on pathological conclusion. Our microscopic findings indicated the DSRCT diagnosis (-Fig. 1). ${ }^{12}$ An additional 
Table 1 Overview of the 16 reported cases of ovarian desmoplastic small round cell tumor

\begin{tabular}{|c|c|c|c|c|c|c|}
\hline $\begin{array}{l}\text { Case } \\
\text { (n) }\end{array}$ & Reference & $\begin{array}{l}\text { Age } \\
\text { (yrs) }\end{array}$ & $\begin{array}{l}\text { Ovarian } \\
\text { involvement }\end{array}$ & Treatment modalities & Chemotherapy protocol & Follow-up \\
\hline 1 & Young et $\mathrm{al}^{24}$ & 15 & $\begin{array}{l}\text { Unknown } \\
\text { laterality }\end{array}$ & $\mathrm{PDS}+\mathrm{SDS}+\mathrm{CHT}$ & $\begin{array}{l}\text { Multi-agent protocol including } \\
\text { carboplatin }\end{array}$ & Succumbed at 4 months \\
\hline 2 & Young et $\mathrm{al}^{24}$ & 15 & Bilateral & PDS + SDS & Not used & Unknown \\
\hline 3 & Young et $\mathrm{al}^{24}$ & 14 & Right & PDS & Unknown, ifused & Unknown \\
\hline 4 & Zaloudek et al ${ }^{25}$ & 22 & Bilateral & $\mathrm{PDS}+\mathrm{CHT}$ & BEP & Succumbed at 18 months \\
\hline 5 & Slomovitz et $\mathrm{al}^{26}$ & 11 & Right & $\mathrm{PDS}+\mathrm{CHT}+\mathrm{ASCS}$ & $\begin{array}{l}\text { Modified P6 + myeloablative } \\
\text { chemotherapy }\end{array}$ & Succumbed at 11 months \\
\hline 6 & Parker et al ${ }^{27}$ & 23 & Right & $\mathrm{PDS}+\mathrm{CHT}$ & Platinum and taxol chemotherapy & Unknown \\
\hline 7 & Elhajj et $\mathrm{al}^{23}$ & 27 & Bilateral & $\mathrm{PDS}+\mathrm{CHT}$ & Delayed C/E followed by CAV & Succumbed at 42 months \\
\hline 8 & Ota et $\mathrm{al}^{1}$ & 26 & Bilateral & $\mathrm{PDS}+\mathrm{CHT}+\mathrm{SDS}+\mathrm{RT}$ & P6 & Succumbed at 23 months \\
\hline 9 & Ota et al ${ }^{1}$ & 19 & Bilateral & $\mathrm{PDS}+\mathrm{CHT}+\mathrm{SDS}$ & BEP & Succumbed at 11 months \\
\hline 10 & Fang et al ${ }^{14}$ & 13 & Left & $\mathrm{PDS}+\mathrm{CHT}+\mathrm{RT}$ & BEP & Succumbed at 21 months \\
\hline 11 & Fang et $\mathrm{al}^{14}$ & 23 & Bilateral & $\mathrm{PDS}+\mathrm{CHT}$ & Myeloablative chemotherapy & Alive at 7 months \\
\hline 12 & $\begin{array}{l}\text { Engohan- } \\
\text { Aloghe et al }\end{array}$ & 21 & Bilateral & $\mathrm{PDS}+\mathrm{CHT}$ & unknown & Alive at 7 months \\
\hline 13 & Nakayama et $\mathrm{al}^{28}$ & 6 & Bilateral & $\mathrm{PDS}+\mathrm{CHT}+\mathrm{RT}+\mathrm{CHT}$ & P6 + IMC-A12 trial + temsirolimus & Succumbed at 28 months \\
\hline 14 & Nakayama et $\mathrm{al}^{28}$ & 28 & Right & $\mathrm{CHT}+\mathrm{SDS}$ & $\begin{array}{l}\text { Neoadjuvant P6 } \\
\text { (with the removal of adriamycin) + } \\
\text { topotecan after surgery }\end{array}$ & Succumbed at 40 months \\
\hline 15 & Nakayama et $\mathrm{al}^{28}$ & 17 & Right & $\mathrm{PDS}+\mathrm{CHT}+\mathrm{SDS}+\mathrm{RT}$ & P6 & Alive at 11 months \\
\hline 16 & Xie and Shen ${ }^{2}$ & 30 & Right & $\mathrm{PDS}+\mathrm{CHT}$ & VAC & Alive at 15 months \\
\hline 17 & Present case & 19 & Bilateral & $\begin{array}{l}\mathrm{PDS}+\mathrm{CHT}+\mathrm{SDS}+ \\
\mathrm{RT}+\mathrm{ASCS}\end{array}$ & CWS + Bu-Mel & Alive at 40 months \\
\hline
\end{tabular}

Abbreviations: ASCS, autologous stem cell support; BEP, bleomycin, etoposide and cisplatin; Bu-Mel, busulfan, melphalan; C/E, cisplatin/etoposide; CHT, chemotherapy; CWS, etoposide, idarubicin, and trofosfamide; PDS, primary debulking surgery; RT, radiotherapy; SDS, secondary debulking surgery; VAC, vincristine, adriamycin, and cyclophosphamide.

Source: Modified from Xie and Shen. ${ }^{2}$

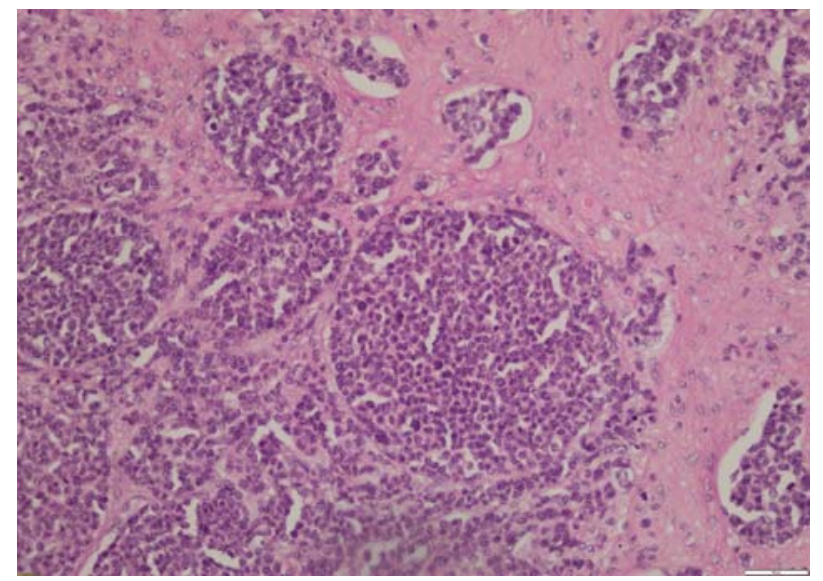

Fig. 1 Microscopic finding of desmoplastic small round cell tumor, hematoxylin and eosin staining. Source: Engohan-Aloghe et al. ${ }^{12}$

important and useful diagnostic tool is the combination of immunohistochemical staining and cytogenetic analysis. The characteristic DSRCT immunophenotype is the coexpression of epithelial, mesenchymal, and neuroendocrine markers. ${ }^{13}$ Furthermore, the small round cells in our material were focal positive for desmin and Wilms tumor 1 (WT-1) genes and were negative for chromogranin, among others, thus helping our pathologist to distinguish DSRCT from other forms of small round cell tumors (e.g., ovarian small cell carcinoma of hypercalcemic type). The expression of immunolabelings in the small round cells showed great level of variability (-Table 2), with positive desmin and broad-spectrum CK being considered the most specific immunological indexes of DSRCT. If the diagnosis is uncertain following microscopic, immunohistochemical, or cytologic analysis, the PCR method or fluorescent in-situ hybridization (FISH) can be helpful in providing supplemental diagnostic information. Desmoplastic small round cell tumor exhibits a unique chromosomal transcription, resulting in the fusion of EWS-WT-1 to create a gene that presumably acts as a transcriptional activator for protumorigenic genes. ${ }^{14}$ Because this chromosomal transcription is not always present ( $\boldsymbol{- T a b l e ~} \mathbf{2}$ ), the efficiency of this diagnostic approach, considering the eventual costs of the diagnostic tools used, is still controversial. Nevertheless, a lot of efforts are still required towards a definition of the most adequate therapeutic modality of choice. Although the multiple treatment strategies have been assessed, DSRCT survival has not significantly improved (- Table 1). Currently, a combination of surgical resection and chemotherapy are commonly used for the initial treatment, although there is no consensus regarding whether surgical debulking should be preceded or followed by chemotherapy. ${ }^{2}$ In one reported study by Lal et al, there is a strong correlation between 3 and 5-year 
Table 2 Result of immunohistochemical studies-expression of immune labelings in part of reported ovarian desmoplastic small round cell tumor cases

\begin{tabular}{|c|c|c|c|c|c|c|c|c|c|c|c|}
\hline Reference & Des & AE1/AE3 & CK7 & Inh & Vim & EMA & NSE & Chr & Actin & WT1 & $\overline{\text { EWS/WT1 (PCR) }}$ \\
\hline 1 & ++ & ++ & - & $\mathrm{N} / \mathrm{A}$ & $\mathrm{N} / \mathrm{A}$ & ++ & $\mathrm{N} / \mathrm{A}$ & - & - & + & NP \\
\hline 1 & ++ & ++ & + & $\mathrm{N} / \mathrm{A}$ & $\mathrm{N} / \mathrm{A}$ & ++ & $\mathrm{N} / \mathrm{A}$ & - & - & + & $\mathrm{P}$ \\
\hline 2 & $++\left(^{*}\right)$ & ++ & $\mathrm{N} / \mathrm{A}$ & - & ++ & ++ & - & $\mathrm{N} / \mathrm{A}$ & $\mathrm{N} / \mathrm{A}$ & $\mathrm{N} / \mathrm{A}$ & $\mathrm{N} / \mathrm{A}$ \\
\hline 12 & $++\left({ }^{*}\right)$ & - & $\mathrm{N} / \mathrm{A}$ & + & $\mathrm{N} / \mathrm{A}$ & - & ++ & - & + & $\mathrm{N} / \mathrm{A}$ & $\mathrm{P}$ \\
\hline 18 & + & $\mathrm{N} / \mathrm{A}$ & $\mathrm{N} / \mathrm{A}$ & $\mathrm{N} / \mathrm{A}$ & + & $\mathrm{N} / \mathrm{A}$ & + & $\mathrm{N} / \mathrm{A}$ & + & $\mathrm{N} / \mathrm{A}$ & $\mathrm{N} / \mathrm{A}$ \\
\hline 19 & + & $\mathrm{N} / \mathrm{A}$ & $\mathrm{N} / \mathrm{A}$ & $\mathrm{N} / \mathrm{A}$ & + & + & + & - & - & $\mathrm{N} / \mathrm{A}$ & $\mathrm{N} / \mathrm{A}$ \\
\hline 19 & + & ++ & $\mathrm{N} / \mathrm{A}$ & $\mathrm{N} / \mathrm{A}$ & ++ & ++ & - & - & ++ & $\mathrm{N} / \mathrm{A}$ & $\mathrm{N} / \mathrm{A}$ \\
\hline 19 & + & ++ & $\mathrm{N} / \mathrm{A}$ & $\mathrm{N} / \mathrm{A}$ & + & ++ & ++ & - & - & $\mathrm{N} / \mathrm{A}$ & $\mathrm{N} / \mathrm{A}$ \\
\hline 21 & + & + & + & $\mathrm{N} / \mathrm{A}$ & $\mathrm{N} / \mathrm{A}$ & $\mathrm{N} / \mathrm{A}$ & $\mathrm{N} / \mathrm{A}$ & $\mathrm{N} / \mathrm{A}$ & $\mathrm{N} / \mathrm{A}$ & $\mathrm{N} / \mathrm{A}$ & $\mathrm{N} / \mathrm{A}$ \\
\hline 23 & + & $\mathrm{N} / \mathrm{A}$ & $\mathrm{N} / \mathrm{A}$ & $\mathrm{N} / \mathrm{A}$ & $\mathrm{N} / \mathrm{A}$ & + & + & $\mathrm{N} / \mathrm{A}$ & $\mathrm{N} / \mathrm{A}$ & $\mathrm{N} / \mathrm{A}$ & $\mathrm{P}$ \\
\hline 23 & ++ & ++ & ++ & N/A & $\mathrm{N} / \mathrm{A}$ & N/A & $\mathrm{N} / \mathrm{A}$ & $\mathrm{N} / \mathrm{A}$ & $\mathrm{N} / \mathrm{A}$ & $\mathrm{N} / \mathrm{A}$ & NP \\
\hline 23 & ++ & ++ & ++ & - & $\mathrm{N} / \mathrm{A}$ & $\mathrm{N} / \mathrm{A}$ & $\mathrm{N} / \mathrm{A}$ & $\mathrm{N} / \mathrm{A}$ & $\mathrm{N} / \mathrm{A}$ & - & $\mathrm{P}$ \\
\hline Present case & + & ++ & - & + & ++ & ++ & - & - & - & + & $P$ \\
\hline
\end{tabular}

Abbreviations: (-), negative; $\left({ }^{*}\right)$, dot-likepattern; $(++)$, diffuse positive; $(+)$, focally positive; AE1/AE3; CK7, cytokeratin markers; Chr, chromogranin; Des, desmin; EMA, epithelial membrane antigen; EWS/WT1, Ewins sarcoma/Wilms tumor 1; Inh, inhibin; N/A, information not available or test was not done; NP, not present; NSE, neuron-specificenolase; P, present; PCR, polymerase chain reaction; Vim, vimentin.

survival with multimodal therapy treatment. A systemic chemotherapy utilizing the P6 regimen, aggressive surgical debulking with greater than $90 \%$ surgical resection, and adjuvant radiotherapy combined demonstrated significant contribution to improved overall survival. ${ }^{15}$ In terms of choice of chemotherapy, DSRCT is alkylator-sensitive and dose-responsive, compared to other small round-cell tumors. ${ }^{16}$ Certain regimens, especially platinum-based ones, showed great overall safety profile and should be considered even in the second and early third trimester of pregnancy. ${ }^{17}$ Scheer et al ${ }^{18}$ demonstrated the best results with the vincristine, adriamycin, ifosfamide, actinomycin D (VAIA) scheme in a multivariable model proven by the Cox regression analysis as an independent effect. The median event-free survival (EFS) of 15 patients treated with VAIA was 29.4 months. Due to the poor prognosis and outcome for patients with DSCRT, we have decided to treat the young girl according to guidelines established by the Cooperative Weichteilsarkom Study (CWS) group in cooperation with the European pediatric SoftTissue Sarcoma Study Group (EpSSG) protocol scheme treatment plan for very high risk/metastatic patients, which we use at our department for the treatment of soft-tissue sarcomas. The CWS guildelines differ from the P6 protocol in number of cycles (P6 has 7 and CWS 9 cycles), and CWS lacks thecyclophospamide, but it has introduced the carboplatin and epirubicine to the first-line chemotherapy treatment (high-dose carboplatin has been used in the P6 protocol as a part of myeloablative regimen with stem-cell rescue). A possible connection with Ewing sarcoma was observed after we performed the PCR analysis and the EWS-WT1 fusion gene was revealed. Both tumors share an EWS fusion protein and may also share molecular mechanisms promoting proliferation and survival pathways. That explains why the vincristine, ifosfamide, doxorubicin, etoposide (VIDE) regimen was chosen to treat some cases, for which Wong et $\mathrm{al}^{19}$ reported a median time to progression of 14.6 months, and Frank et $\mathrm{al}^{20}$ reported survival of 19 months. In our report, the patient was treated with the CWS chemotherapy protocol scheme used for the treatment of rare mesenchymal tumors. The patient is still alive with EFS of 40 months. Furthermore, it is evident that adjuvant chemotherapy following gross total tumor resection is necessary to achieve long-term disease control in DSRCT, as shown in this particular case. Although the P6 regimen has been the cornerstone of initial DSRCT therapy, with great response in the majority of cases, it did not improve overall survival, suggesting an aggressive nature of the disease but also a requisite for another systemic, targeted treatment modality. There is no unique chemotherapy protocol in the treatment of DSRCT; thus, the choice is based on clinician experience or patient protocol indulgement. To our knowledge, our case is the first of all ovarian-involved DSRCT in the English literature to use CWS chemotherapy protocol (-Table 1) with remarkable success. It is important to emphasize that one of the main difficulties in the treatment of DSRCT, due to its adhesive nature, is not achieving optimal surgical debulking, with more than $10 \%$ of tumor left. ${ }^{1,21-27}$ We found optimal surgical debulking to be necessary for local disease control and for establishing better response on adjuvant treatment modalities. Other adjuvant treatment modalities may include hyperthermic intraperitoneal chemotherapy, ${ }^{21,22}$ yttrium microsphere, ${ }^{22}$ or, as presented in our case, high-dose chemotherapy followed by autologous stem-cell support. We demonstrated the efficienty of the treatment modality chosen in this case, which combined primary and secondary surgical debulking, CWS chemotherapy protocol, and boost radiotherapy joined with high-dose chemotherapy followed by autologous stem cell support. The young woman from our case is still alive 40 months after the treatment, with great probability of 
being the patient with the longest survival period observed, ${ }^{23}$ since in her most recent follow-up appointment, in July of the present year, tno tumor disease was observed and she presented good overall physical and mental condition.

\section{Conclusion}

Desmoplastic small round cell tumor is an unusual and remarkably malignant tumor that affects the young population, with a small number of long-term survivals. An increasing number of patients has been diagnosed with DSRCT over past decade, and, with improvement of our overall knowledge, especially about the molecular mechanisms and signal pathways involved in the tumor pathogenesis, we can expect further advances in treatment. Although the best therapy for patients with DSRCT has yet to be determined, combining complete surgical resection, adjuvant chemotherapy, and radiotherapy is required to prolong survival and to achieve proper quality of life.

\section{Conflict of Interests}

The authors have no conflict of interests to declare.

\section{References}

1 Ota S, Ushijima K, Fujiyoshi N, Fujimoto T, Hayashi R, Murakami F, et al. Desmoplastic small round cell tumor in the ovary: Report of two cases and literature review. J Obstet Gynaecol Res. 2010;36 (02):430-434. Doi: 10.1111/j.1447-0756.2009.01126.x

2 Xie YP, Shen YM. Ovarian involvement of a desmoplastic small round cell tumor of unknown primary origin with lymph node and lung metastases: A case report. Oncol Lett. 2016;11(02): 1125-1129. Doi: 10.3892/ol.2015.4012

3 Lettieri CK, Garcia-Filion P, Hingorani P. Incidence and outcomes of desmoplastic small round cell tumor: results from the surveillance, epidemiology, and end results database. J Cancer Epidemiol. 2014;2014:680126. Doi: 10.1155/2014/680

4 Gerald WL, Rosai J. Case 2. Desmoplastic small cell tumor with divergent differentiation. Pediatr Pathol. 1989;9(02):177-183. Doi: $10.3109 / 15513818909022347$

5 Church DN, Bailey J, Hughes J, Williams CJ. Desmoplastic small round cell tumour: obstetric and gynecological presentations. Gynecol Oncol. 2006;102(03):583-586. Doi: 10.1016/j. ygyno.2006.03.025

6 Gerald WL, Ladanyi M, de Alava E, Cuatrecasas M, Kushner BH, LaQuaglia MP, Rosai J. Clinical, pathologic, and molecular spectrum of tumors associated with $\mathrm{t}(11 ; 22)(\mathrm{p} 13 ; \mathrm{q} 12)$ : desmoplastic small round-cell tumor and its variants. J Clin Oncol. 1998;16(09): 3028-3036. Doi: 10.1200/jco.1998.16.9.3028

7 Lae ME, Roche PC, Jin L, Lloyd RV, Nascimento AG. Desmoplastic small round cell tumor: a clinicopathologic, immunohistochemical, and molecular study of 32 tumors. Am J Surg Pathol. 2002;26 (07):823-835. Doi: 10.1097/00000478-200207000-00001

8 Quaglia MP, Brennan MF. The clinical approach to desmoplastic small round cell tumor. Surg Oncol. 2000;9(02):77-81. Doi: 10.1016/s0960-7404(00)00024-4

9 Schwarz RE, Gerald WL, Kushner BH, Coit DG, Brennan MF, La Quaglia MP. Desmoplastic small round cell tumors: prognostic indicators and results of surgical management. Ann Surg Oncol. 1998;5(05):416-422. Doi: 10.1007/bf02303860

10 Li X, Yu J, Fang S, Xing X, Zhao J. Desmoplastic small round cell tumor: a case report and review of the literature. World J Surg Oncol. 2014;12:9. Doi: 10.1186/1477-7819-12-9
11 Kushner BH, LaQuaglia MP, Wollner N, et al. Desmoplastic small round-cell tumor: prolonged progression-free survival with aggressive multimodality therapy. J Clin Oncol. 1996;14(05): 1526-1531. Doi: 10.1200/jco.1996.14.5.1526

12 Engohan-Aloghe C, Aubain Sommerhausen NdeS, Noël JC. Ovarian involvement by desmoplastic small round cell tumor with leydig cell hyperplasia showing an unusual immunophenotype (cytokeratin negative, calretinin and inhibin positive) mimicking poorly differentiated sertoli leydig cell tumor. Int J Gynecol Pathol. 2009;28(06):579-583. Doi: 10.1097/pgp.0b013e3181aae8dc

13 Ordóñez NG. Desmoplastic small round cell tumor: II: an ultrastructural and immunohistochemical study with emphasis on new immunohistochemical markers. Am J Surg Pathol. 1998;22 (11):1314-1327. Doi: 10.1097/00000478-199811000-00002

14 Fang X, Rodabaugh K, Penetrante R, Wong M, Wagner T, Sait T, Mhawech-Fauceglia P. Desmoplastic small round cell tumor (DSRCT) with ovarian involvement in 2 young women. Appl Immunohistochem Mol Morphol. 2008;16(01):94-99. Doi: 10.1097/01.pai.0000213158.71934.9c

15 Lal DR, Su WT, Wolden SL, Loh KC, Modak S, La Quaglia MP. Results of multimodal treatment for desmoplastic small round cell tumors. J Pediatr Surg. 2005;40(01):251-255. Doi: 10.1016/j. jpedsurg.2004.09.046

16 Zhang S, Zhang Y, Yu YH, Li J. Complete response of giant desmoplastic small round cell tumor treated with chemoradiotherapy: A case report. Oncol Lett. 2016;11(02):1069-1072. Doi: 10.3892/ ol.2015.4024

17 Neff RT, Kellert B, Isley M, Backes F. Management of a rapidly enlarging new adnexal mass: a rare case of desmoplastic small round cell tumor of the ovary arising in pregnancy. Gynecol Oncol Rep. 2016;17:23-25. Doi: 10.1016/j.gore.2016.05.008

18 Scheer M, Vokuhl C, Blank B, Hallmen E, von Kalle T, Münter M, et al; Cooperative Weichteilsarkom Studiengruppe [CWS]. Desmoplastic small round cell tumors: Multimodality treatment and new risk factors. Cancer Med. 2019;8(02):527-542. Doi: 10.1002/ cam4.1940

19 Wong HH, Hatcher HM, Benson C, Al-Muderis O, Horan G, Fisher C, et al. Desmoplastic small round cell tumour: characteristics and prognostic factors of 41 patients and review of the literature. Clin Sarcoma Res. 2013;3(01):14. Doi: 10.1186/2045-33293-14

20 Frank JA, Ranft A, Paulussen M, Juergens H, Kruseova J, Bauer S, et al. Results for patients with sarcoma not otherwise specified and other diagnoses than Ewing sarcoma treated according to the Euro-EWING 99 trial. Pediatr Blood Cancer. 2017;64(10):e26524. Doi: $10.1002 / p b c .26524$

21 Guerrero WL, Munene G, Dickson PV, Darby D, Davidoff AM, Martin MG, et al. Early experience with cytoreduction and hyperthermic intraperitoneal chemotherapy at a newly developed center for peritoneal malignancy. J Gastrointest Oncol. 2018; 9(02):338-347. Doi: 10.21037/jgo.2018.01.02

22 Hayes-Jordan A, Anderson PM. The diagnosis and management of desmoplastic small round cell tumor: a review. Curr Opin Oncol. 2011;23(04):385-389. Doi: 10.1097/cco.0b013e3283477aab

23 Elhajj M, Mazurka J, Daya D. Desmoplastic small round cell tumor presenting in the ovaries: report of a case and review of the literature. Int J Gynecol Cancer. 2002;12(06):760-763. Doi: 10.1046/j.1525-1438.2002.01132.x

24 Young RH, Eichhorn JH, Dickersin GR, Scully RE. Ovarian involvement by the intra-abdominal desmoplastic small round cell tumor with divergent differentiation: a report of three cases. Hum Pathol. 1992;23(04):454-464. Doi: 10.1016/0046-8177(92) 90094-j

25 Zaloudek C, Miller TR, Stern JL. Desmoplastic small cell tumor of the ovary: a unique polyphenotypic tumor with an unfavorable prognosis. Int J Gynecol Pathol. 1995;14(03):260-265. Doi: 10.1097/00004347-199507000-00011 
302 Desmoplastic Small Round Cell Tumor of the Ovary Vujić et al.

26 Slomovitz BM, Girotra M, Aledo A, Saqi A, Soslow RA, Spigland NA, Caputo TA. Desmoplastic small round cell tumor with primary ovarian involvement: case report and review. Gynecol Oncol. 2000;79(01):124-128. Doi: 10.1006/gyno.2000.5829

27 Parker LP, Duong JL, Wharton JT, Malpica A, Silva EG, Deavers MT. Desmoplastic small round cell tumor: report of a case presenting as a primary ovarian neoplasm. Eur J Gynaecol Oncol. 2002;23 (03):199-202

28 Nakayama J, Nassau S, Atkins K, Modesitt SC. Desmoplastic small round cell tumor of the ovary: A rare but devastating disease in young women. Gynecol Oncol Case Rep. 2013;7:16-18. Doi: 10.1016/j.gynor.2013.02.006 